\title{
ZNAJOMOŚĆ ZACHOWAŃ WIDOWNI NA PODSTAWIE DANYCH STATYSTYCZNYCH: LONDYN I AMSTERDAM W POŁOWIE LAT 30. XX WIEKU
}

Chodźmy obejrzeć dobry film, albo do drugiego domu w Finsbury Park, czy coś w tym rodzaju, usiądźmy na najlepszych miejscach, dla siebie kupisz cygaro, a dla mnie - chociaż raz - czekoladki, i zróbmy to należycie. No, chodźmy. Co ty na to?

Pani Smeeth do pana Smeetha w powieści Angel Pavement J. B. Priestleya ${ }^{1}$.

Dwójka bohaterów powyższego monologu to postacie fikcyjne, a mimo to swą rozmową dają nam wiarygodny obraz procesu decyzyjnego pary przedstawicieli klasy robotniczej w średnim wieku, która decyduje się na wyjście do kina w określonym miejscu i w określonym czasie. Co ciekawe, w monologu nie pada tytuł głównego filmu z repertuaru - tak jakby projekcja była jedynie tłem dla całego rynsztunku kina i jego personelu. W istocie, można pomyśleć, iż najważniejszą atrakcją w oczach naszej pary był tytoń dla pana Smeetha oraz słodycze dla pani Smeeth.

W 1930 roku, kiedy opublikowana została powieść Angel Pavement, w leżącym na przedmieściach północnego Londynu Finsbury Park znajdowały się dwa kina: mający długą historię, mieszczący 2092 osoby Finsbury Park, będący częścią brytyjskiej sieci Gaumont, a także, od września, utrzymane w nowym, „atmosferycznym" stylu kino Astoria (na 3000 miejsc, które wkrótce założycielom odebrać miał Paramount $)^{2}$. W Finsbury Park wyświetlano filmy natychmiast po ich otrzymaniu, zazwyczaj kilka miesięcy po premierze w londyńskim West Endzie. Po pierwszych pokazach na przedmieściach Londynu filmy te rozprzestrzeniały się, trafiając do niższej klasy kin drugiego obiegu, które na ogół odznaczały się niewielkim rozmiarem i niskimi cenami, wyświetlając jednocześnie więcej filmów tygodniowo niż ich prestiżowe odpowiedniki. Ten kaskadowy proces trwał

1 J. B. Priestley, Angel Pavement, Heinneman: London 1930, s. 306.

2 A. Eyles, Gaumont British Cinemas, British Film Institute: London 1996, s. 206. Astoria zamieni się później w Rainbow Room, a do dziś przetrwa jako kościół zielonoświątkowców, podczas gdy Finsbury Park w rejestrze figurować będzie jako kręgielnia. 
aż do osiągnięcia najniższego poziomu. W latach 30. w Wielkiej Brytanii okres między premierami największych filmowych atrakcji a ich definitywnym wycofaniem z obiegu mógł trwać nawet rok, jednakże dane te znacznie się od siebie różniły, podobnie jak liczba kin wyświetlających którykolwiek z tych filmów3.

W sposób przypominający zaproponowany przez Priestleya literacki opis procesu decyzyjnego, Douglas Gomery utrzymuje, iż dla widowni odwiedzającej w latach 20. chicagowskie kina Balaban \& Katz największą atrakcją nie był główny pokaz filmu, ale sam splendor kin wraz z wysokiego kalibru występami na żywo będącymi częścią repertuaru ${ }^{4}$. A więc, jeśli podjęcie decyzji przez państwo Smeeth byłoby w jakikolwiek sposób typowe dla widzów odwiedzających kina, wówczas dochód z biletów w Finsbury Park byłby w mniejszym lub w większym stopniu stały, a większego wpływu nie miałby nań repertuar. Jeśli chodzi o kina Balaban \& Katz, na zróżnicowanie poziomu zysków w większym stopniu miała wpływ prawdopodobnie atrakcyjność występów na żywo. Jednakże na podstawie naszej wiedzy na temat dalece niesymetrycznego rozłożenia dochodów ze sprzedaży biletów - odnotowanego w Stanach Zjednoczonych, w cotygodniowych $\mathrm{z}$ raportach sprzedażowych kin premierowych całego kraju, publikowanych w „Motion Picture Herald” i „Variety” na tygodniowych fakturach kin sieci Stanley Warner Theaters w Filadelfii ${ }^{6}$, a także w Wielkiej Brytanii, w księgach głównych poświęconych Empire na Leicester Square ${ }^{7}$ oraz Regent w Portsmouth ${ }^{8}$ - należy stwierdzić, iż ogromna część widowni odwiedzającej kina premierowe była $\mathrm{w}$ dużej mierze przyciągana przez same filmy, jakkolwiek w kinach o niższej hierarchii grupa ta wydaje się być mniejsza. Według Richarda Maltby’ego Hollywood najwyraźniej to zrozumiało, produkując szeroki wachlarz filmów „skierowanych do wielu zróżnicowanych grup widzów"

${ }^{3}$ J. Sedgwick, Popular Fimgoing in 1930s Britain: A Choice of Pleasures, Exeter University Press: Exeter 2000, tabele: 5.4, 6.1, 6.6 oraz 6.7.

${ }^{4}$ D. Gomery, Shared Pleasures: A History of Movie Presentation in the United States, British Film Institute: London 1992, s. 55.

${ }^{5}$ H. M. Glancy, J. Sedgwick, Cinema Going in the United States in the Mid-1930s: A Study Based on the Variety Dataset, [w:] Going to the Movies: Hollywood and the Social Experience of Cinema, eds. R. Maltby, M. Stokes, R. Allen, Exeter University Press: Exeter 2007, oraz J. Sedgwick, M. Pokorny, The Film Business in the U.S. and Britain During the 1930s, „Economic History Review” 2005, No. 58, s. 79-112.

6 J. Sedgwick, M. Pokorny, Film Consumer Decision-Making: The Philadelphia Story 1935-36, „Journal of Consumer Culture” 2012, No. X.

7 A. Eyles, The Empire That Was, 1928-61, „Picture House” 1989, No. 13.

8 J. Sedgwick, Cinemagoing in Portsmouth During the 1930s, „Cinema Journal” 2006, No. 46 , s. 52-85.

9 R. Maltby, Sticks, Hicks and Flaps: Classical Hollywood's Generic Conception of Its Audiences, [w:] Identifying Hollywood's Audiences: Cultural Identity and the Movies, eds. M. Stokes, R. Maltby, British Film Institute: London, s. 25. 
Tego typu informacje o publiczności są istotne dla filmoznawców. Stanowią rodzaj wspólnego mianownika dla decyzji podejmowanych przez najważniejsze podmioty - producentów filmowych, dystrybutorów, kiniarzy i widownię. Dostarczają tym samym solidnych podstaw do zrozumienia zachowań tychże podmiotów i teoretycznego ich ujęcia. W odniesieniu do typów widowni, które były mocno zróżnicowane w zależności od filmów, możemy na podstawie liczby widzów zbadać ich upodobania: dlaczego, na przykład, czasem poszczególne obrazy wzbudzały duże zainteresowanie tylko w niektórych kinach, podczas gdy w innych przypadkach w tej samej miejscowości różnic we frekwencji nie odnotowano w ogóle?

Autorzy przeprowadzili badania, aby ustalić, do jakiego stopnia „wielkie wydarzenia" filmowe, a więc realizacje, które - w porównaniu ze średnią frekwencją w danym kinie - przyciągały w czasie premiery niezwykle dużą liczbę widzów; były też atrakcyjne dla publiczności, gdy wchodziły do kin niższej klasy. Naszą uwagę zwraca zatem funkcja pierwszego obiegu w wydobywaniu kasowego potencjału. Filmy te były następnie przekazywane do kin niższej klasy i kierowane do innych typów widowni - do widzów, dla których sama wizyta w kinie była prawdopodobnie największą atrakcją, tak jak w przypadku państwa Smeeth. Niemniej jednak, w obliczu braku danych na temat zysków ze sprzedaży biletów, niemożliwe jest przeanalizowanie rzeczywistych różnic w upodobaniach publiczności odwiedzającej konkretne kina ${ }^{10}$. Można tego dokonać poprzez przedstawienie na - wykresach i w pomiarach - rozprzestrzeniania się filmów w kinach, w konkretnym obszarze geograficznym: krajowym, regionalnym bądź lokalnym.

Odwołująć się do metody POPSTAT ${ }^{11}$, autorzy niniejszego artykułu najpierw przeanalizują dystrybucję filmów, które miały swoją premierę w Empire na Leicester Square, po czym trafiły do kin w Bolton w północno-zachodniej Anglii (populacja: około 180000 mieszkańców) oraz do znajdującego się na południowym wybrzeżu Brighton (populacja: około 200000 mieszkańców). Podobny zabieg zostanie wykonany w odniesieniu do Holandii, tym razem koncentrując się na zapisach dotyczących pokazów w kinie Tuschinski w Amsterdamie oraz na liczbie pokazywanych tam filmów, które następnie były wyświetlane w Tilburgu (populacja: 84967 mieszkańców w 1934 roku) leżącym w południowej części Holandii, nieopodal granicy z Belgią, oraz w Utrechcie, leżącym w centrum kraju (populacja: 159895 mieszkańców w 1934 roku). W ten sposób zestawieni ze sobą zostaną zamieszkujący metropolie widzowie kin pierwszego obiegu w obu krajach, ale też formuły rozprowadzania filmów w dużych, prowincjonalnych miastach.

10 Podobnie jak w przypadku archiwów wielu innych historycznych przedsiębiorstw, wydaje się, że znaczna większość głównych ksiąg kas biletowych została zniszczona. Wspomnimy o tej liczbie w dalszej części badania.

11 Na temat POPSTAT zob. J. Sedgwick, Popular Filmgoing in 1930s Britain..., s. 70-73. 


\section{Dane z kas biletowych (1932-1937)}

Empire na Leicester Square było kinem wytwórni MGM w Wielkiej Brytanii. Szczęśliwie jesteśmy w posiadaniu publikacji Allena Eylesa, dotyczącej tygodniowych repertuarów i frekwencji w kinach. Frekwencja ta - zgodnie z naszą wiedzą - nie była dotychczas systematycznie analizowana. Mogące pomieścić 3226 widzów Empire było największym londyńskim kinem w obszarze West End. W połowie lat 30. ceny w Empire wynosily od 1/6 (18 pensów) do 6/- (72 pensy) $)^{12}$. Dla porównania, Browning i Sorrell oszacowali średnią cenę biletów w Wielkiej Brytanii w tym okresie na ponad 10 pensów $^{13}$. W latach 1932-1937 Empire wyświetliło 303 filmy. Dwieście z nich pochodziło z hollywoodzkiego studia MGM, podczas gdy siedem (sześć obrazów z Laurelem i Hardym oraz Niewidzialne matżeństwo, 1937) przypisanych jest studiu Hala Roacha. Niemal wszystkie realizacje MGM miały swoje pierwsze pokazy w Empire ${ }^{14}$. Wszystkie największe filmy pokazywano $\mathrm{w}$ ramach pojedynczych seansów, których $\mathrm{w}$ przeciągu sześciu lat było 149. Pozostałe 154 wyświetlano w formie podwójnych seansów, będących odpowiedzią na wymogi ustawy o kinematografii z 1927 roku, zmuszającej kiniarzy i dystrybutorów do zwiększania liczby rodzimych produkcji, przez co ich liczba wzrosła o 20 procent w $1936 \mathrm{roku}^{15}$. MGM pokazywał więc niskobudżetowe filmy produkowane w mniejszych brytyjskich studiach, zanim jeszcze w 1938 roku wprowadzono ustawę o kinematografii wraz z - powiązanymi z budżetem - wytycznymi na temat minimalnej liczby wyświetlanych produkcji rodzimych.

Wykres 1. odnosi się do grupy filmów, które w ramach zintegrowanej rozrywki wyświetlane były $\mathrm{w}$ formie podwójnych pokazów w Empire w latach 1932-1937. Obejmuje on 225 osobnych, pionowych słupków - po jednym dla każdej pakietu ${ }^{16}$. Niewielka liczba tych filmów nie miała swojej premiery w Em-

${ }_{12}$ Jeden (szyling) i sześć (pensów) (18 pensów sprzed systemu dziesiętnego) do sześciu (szylingów) (72 pensy sprzed systemu dziesiętnego). Na funta w ówczesnym systemie składało się 240 pensów.

13 Zob. H. E. Browning, A. A. Sorrell, Cinemas and Cinema-Going in Great Britain, "Journal of the Royal Statistical Society, Series A (General)" 1954, No. 117.

${ }^{14} \mathrm{Z}$ jakiegoś powodu film Gdy kwitna bzy (Maytime, 1937) wytwórni MGM miał swoją premierę w Carlton, co może dziwić, ponieważ kino to należało do sieci Paramount i zazwyczaj wyświetlało „hity” tejże wytwórni.

${ }_{15}$ Zob. J. Sedgwick, Popular Filmgoing in 1930s Britain..., s. 51-54.

${ }_{16}$ Brakuje zapisów dotyczących dwóch filmów. Jeśli chodzi o Pilnuj swojego męża (Tugboat Annie, 1933), którego premiera odbyła się 8 września 1933 roku, nie posiadamy danych z kas biletowych z pierwszego tygodnia pokazów. Jednakże liczba 37020 sprzedanych biletów w ciągu drugiego tygodnia pozwala mi zakładać, iż w trakcie pierwszego wyniosła ono około 50 000. Zapisów dotyczących filmu Another Language (1933) brakuje natomiast w całości. Eyles, „The Empire That Was” 1928, No. 61, s. 27. 
pire, ale w tak zwanych kinoteatrach o „dobrej renomie” ( $w$ teatrologii termin ten wywodzi się z Licensing Act z 1737 roku, w którym dokonano podziału na teatry o dobrej i złej renomie - na deskach tych pierwszych wystawiano poważne utwory, prawdopodobnie podlegające politycznej cenzurze, natomiast te drugie oferowały beztroską rozrywkę uważaną jednak ówcześnie za nieszkodliwą). Choć dzisiaj podział ten nie ma związku z cenzurą, często jest wykorzystywany przez podmioty dobrze znające tajniki show-biznesu, takie jak Variety, w celu zwykłego odróżnienia kinoteatru od teatru wystawiającego na ogół produkcje na scenie - przykładem tych drugich na londyńskim West Endzie były Palace, teatr His Majesty's oraz Hippodrome. Do takich realizacji należały (w porządku zgodnym z datą premiery): Kolacja o ósmej (Dinner at Eight, 1933) (osiem tygodni w Palace, a następnie dwa tygodnie w Empire), David Copperfield (1935) (osiem tygodni w Palace, a następnie dwa tygodnie w Empire), Wielki Ziegfeld (The Great Ziegfeld, 1936) (sześć tygodni w His Majesty's, a następnie siedem tygodni w Hippodrome oraz dwa tygodnie w Empire), Romeo i Julia (Romeo and Juliet, 1936) (osiem tygodni w His Majesty's, a następnie tylko jeden tydzień, w ramach podwójnego seansu, w Empire) i w końcu Ziemia btogostawiona (The Good Earth, 1937) (dwanaście tygodni w Palace, a następnie dwa tygodnie w Empire). W ten sposób filmy te - zanim jeszcze trafily do Empire, wizytówki MGM - miały organizowane dodatkowe pokazy. Logika, jaka kryła się za tą praktyką, polegała przede wszystkim na tym, że oczekiwany poziom popytu na te filmy pozwalał dystrybutorowi przypuszczać, iż „wyższe sfery” Londynu będą gotowe zapłacić za bilet w kinoteatrach „o dobrej renomie”, dużo znakomitszych od tych znajdujących się przy Empire. Dowody na to można znaleźć w aneksie, który obrazuje fakt, iż ceny biletów na pięć wyżej wymienionych filmów w kinoteatrach „o dobrej renomie" spadały w trakcie ich wyświetlania, prawdopodobnie dlatego, że widownia wykupywała już tańsze miejsca. Niemniej jednak ceny te - sięgające kwot od 35,25 do 58,20 pensów, ale zazwyczaj powyżej 40 - nadal były znacznie wyższe niż średnia, jaką trzeba było zapłacić w Empire. Na przykład, w trakcie sześciu tygodni wyświetlania Buntu na Bounty (Mutiny on the Bounty, 1935) średnia cena wynosiła od 29,95 (pierwszy tydzień) do 27,20 pensów (szósty tydzień) ${ }^{17}$.

Wykres 1. przedstawia też, $w$ jakim stopniu udział w niewielkiej liczbie wydarzeń filmowych w Empire w okresie tego badania przewyższał średnią frekwencję. Dwanaście filmów - przełamując ogólną tendencję - znajduje się w przedziale gromadzącym przeszło 150000 widzów, podczas gdy średnia wartość wynosi jedynie 34 305. Spadek frekwencji powiązany z pozycją w rankingu filmów/ programów wyświetlanych w Empire jest przedstawiony na wykresie 2., wykazującym również zależność, według której gwałtownie spada część dystrybucji

${ }_{17}$ Informacje na temat dochodów z pokazów Buntu na Bounty pochodzą z Allen Eyles Collection. 
filmów mających wysoki poziom. Można więc zaobserwować znaczące różnice $\mathrm{w}$ zestawieniu z postępującym spłaszczeniem poziomu dystrybucji, generującym to, co statystycy nazywają pozytywną krzywą dystrybucji, w ramach której między pozycjami zachodzą coraz mniejsze różnice w dochodach ${ }^{18}$.

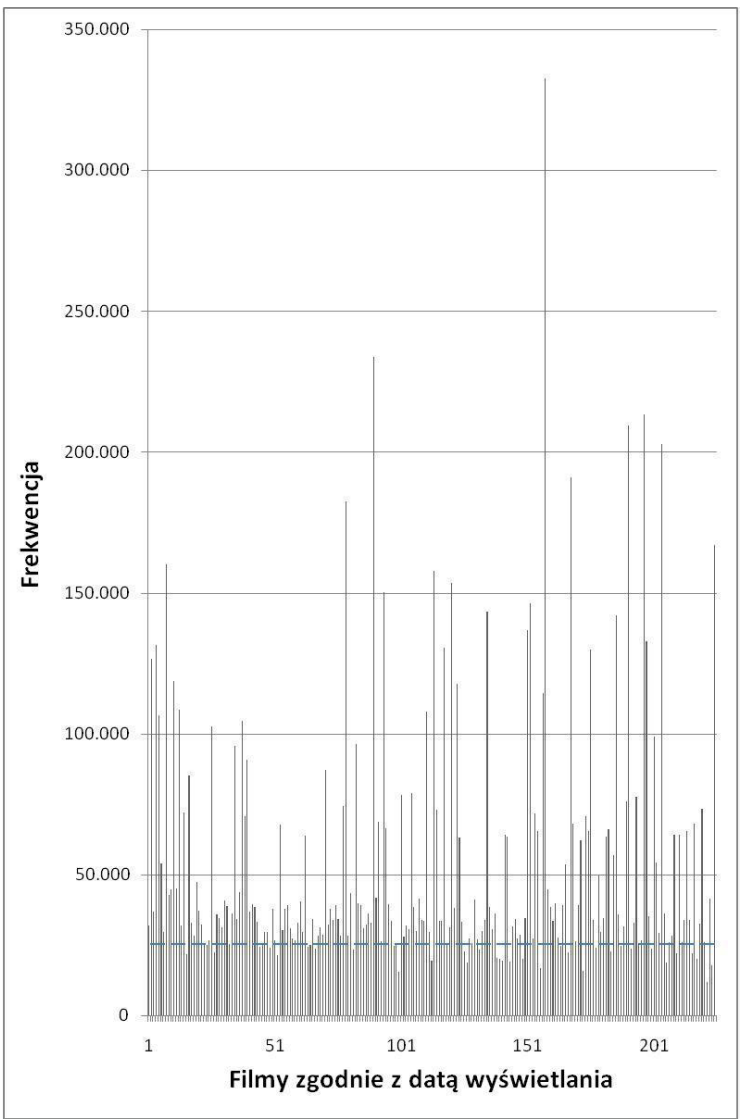

Wykres 1. Frekwencja w kinie Empire na Leicester Square (łącznie z pięcioma filmami, które pokazywane były wcześniej w jednym z trzech renomowanych [legitimate] kinoteatrach) zgodnie z porządkiem chronologicznym, 1932-1937

Źródło: A. Eyles, The Empire That Was, 1928-61 ...; Eyles Collection

${ }_{18}$ Zob. J. Sedgwick, Patterns in First-run and Suburban Filmgoing in Sydney in the Mid-1930s, [w:] The New Cinema History: Approaches and Case Studies, eds. R. Maltby, D. Biltereyst, P. Meers, Wiley-Blackwell, Malden, Oxford 2011, tabela 7.4(a), dla podobnego sposobu występowania popularnych filmów w 1934 roku wyprowadzonych z premierowych kin w Sydney, w Australii. 
Znajomość zachowań widowni na podstawie danych statystycznych... 209

Trzydzieści najlepszych filmów (wszystkie będące produkcjami MGM) $\mathrm{z}$ tego okresu przedstawia tabela 1. Dzięki zestawieniu możemy zauważyć, jak wcześniejsze pokazy w kinoteatrach „o dobrej renomie” wpłynęly na frekwencję na projekcjach wspomnianych pięciu filmów wyświetlanych w Empire. Z wykazu wynika, jak wszechobecne były filmy z udziałem Grety Garbo, Clarka Gable’a, Normy Shearer, Wallace'a Beery'ego i Williama Powella, a w mniejszym stopniu te z Joan Crawford, Marie Dressler, Jean Harlow, Myrną Loy czy Jeanette MacDonald. Wachlarz ekranowych osobowości odgrywanych przez te gwiazdy oraz duża różnorodność filmów, w których się pojawiały, jest świadectwem kreatywnej siły filmowców związanych kontraktem z MGM.

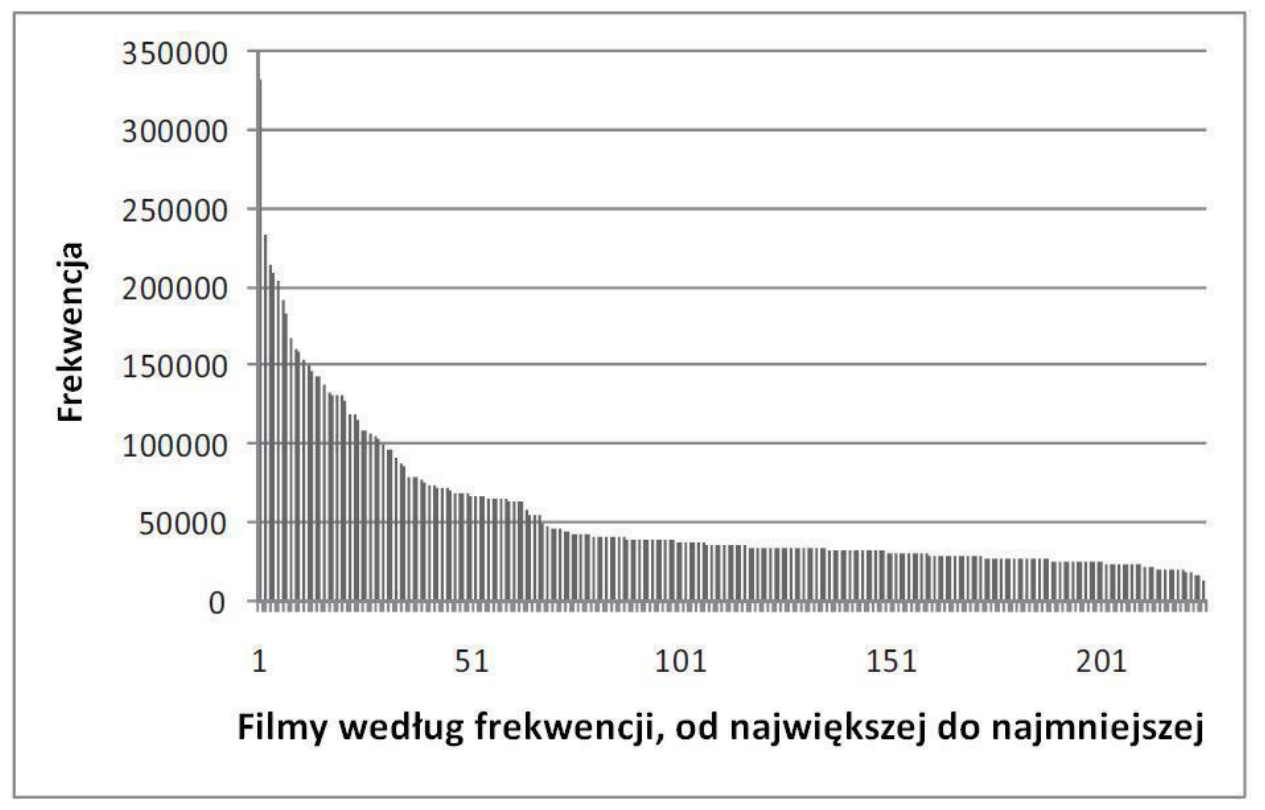

Wykres 2. Frekwencja w Empire na Leicester Square, 1932-1937

Źródło: A. Eyles, The Empire That Was, 1928-61..., 1981; rękopis w BFI, brak daty. 


\begin{tabular}{|c|c|c|c|c|c|c|c|c|}
\hline 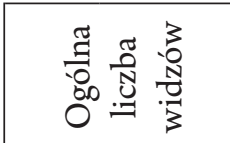 & $\begin{array}{l}0 \\
0 \\
i \\
n \\
\tilde{n} \\
n\end{array}$ & $\mid \begin{array}{l}\infty \\
\infty \\
\infty \\
\tilde{\pi} \\
\tilde{\sim}\end{array}$ & 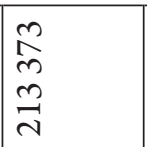 & 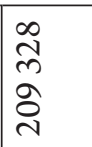 & 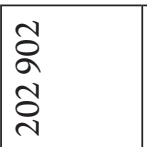 & $\mid \begin{array}{l}n \\
0 \\
\infty \\
2 \\
1\end{array}$ & $\begin{array}{l}8 \\
\vdots \\
+ \\
2 \\
0 \\
1 \\
-1\end{array}$ & $\begin{array}{l}\overrightarrow{7} \\
\text { ठ } \\
-1\end{array}$ \\
\hline 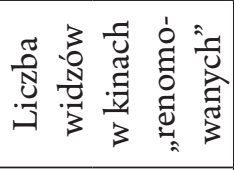 & & & & $\begin{array}{l}0 \\
0 \\
\infty \\
0 \\
0 \\
-1\end{array}$ & 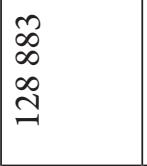 & & 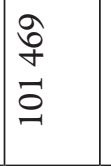 & \\
\hline 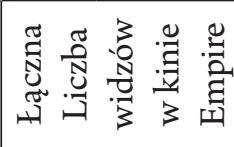 & $\begin{array}{l}0 \\
0 \\
n \\
w \\
w \\
w\end{array}$ & $\begin{array}{l}\infty \\
\infty \\
0 \\
\infty \\
\\
\end{array}$ & $\mid \begin{array}{c}m \\
\infty \\
m \\
\sim \\
\sim\end{array}$ & $\begin{array}{l}\infty \\
\vdots \\
\vdots \\
\infty \\
1\end{array}$ & $\mid \begin{array}{l}3 \\
\dot{0} \\
\dot{1}\end{array}$ & $\mid \begin{array}{l}0 \\
0 \\
\infty \\
2 \\
1\end{array}$ & $\begin{array}{l}\vec{\sigma} \\
\partial \\
\partial\end{array}$ & $\begin{array}{l}\bar{z} \\
\text { ठे } \\
-1\end{array}$ \\
\hline 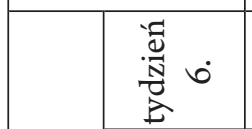 & $\begin{array}{l}\tilde{N} \\
\tilde{D} \\
\infty \\
\infty \\
\infty\end{array}$ & & & & & & & \\
\hline 的 & \begin{tabular}{|l} 
\\
$\alpha$ \\
$\alpha$ \\
$\alpha$ \\
\end{tabular} & & & & & & & \\
\hline 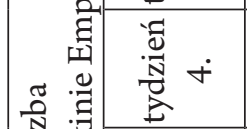 & 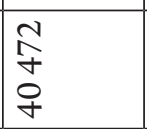 & $\begin{array}{l}0 \\
\infty \\
n \\
m \\
m\end{array}$ & $\begin{array}{l}\text { N } \\
\infty \\
j \\
j\end{array}$ & & & $\begin{array}{l}n \\
\hat{n} \\
i\end{array}$ & & $\begin{array}{l}\text { त } \\
\text { ज } \\
\text { m }\end{array}$ \\
\hline 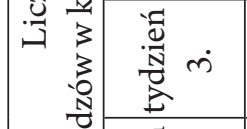 & 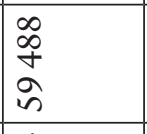 & $\begin{array}{l}0 \\
0 \\
0 \\
b \\
n \\
m\end{array}$ & 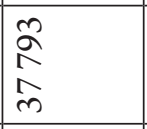 & & & 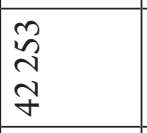 & & $\begin{array}{l}\overline{7} \\
F\end{array}$ \\
\hline 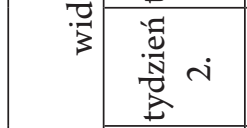 & $\begin{array}{l}0 \\
0 \\
0 \\
n \\
b\end{array}$ & \begin{tabular}{|l} 
D \\
0 \\
0 \\
0 \\
0
\end{tabular} & 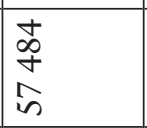 & 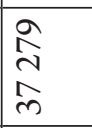 & \begin{tabular}{|l}
0 \\
0 \\
0 \\
$m$ \\
$m$
\end{tabular} & 要 & $\begin{array}{l}\infty \\
\infty \\
\infty \\
m\end{array}$ & $\begin{array}{l}\frac{0}{n} \\
\vdots \\
y\end{array}$ \\
\hline 离 & $\begin{array}{l}\infty \\
2 \\
2 \\
\vdots \\
\infty \\
\infty\end{array}$ & 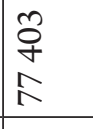 & 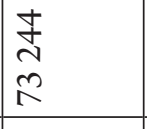 & $\begin{array}{l}a \\
\vec{f} \\
\vec{f}\end{array}$ & {$\left[\begin{array}{ll}0 \\
0 \\
n \\
a \\
a\end{array}\right.$} & $\begin{array}{l}0 \\
0 \\
\beta \\
0\end{array}$ & 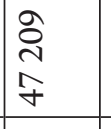 & 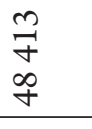 \\
\hline 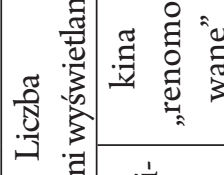 & & & & $\cong$ & $\cong$ & & $\infty$ & \\
\hline 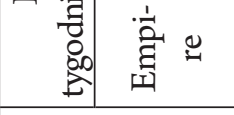 & 6 & t & t & $\sim$ & $\sim$ & t & N & + \\
\hline 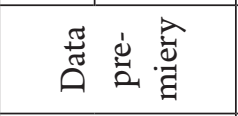 & 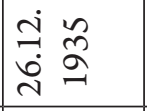 & 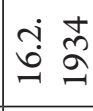 & $\dot{m} \stackrel{\hat{n}}{\Omega}$ & 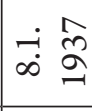 & 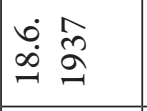 & 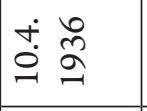 & $\begin{array}{ll}\vec{I} & 0 \\
& \Omega\end{array}$ & 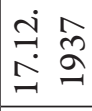 \\
\hline 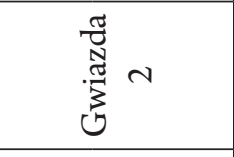 & 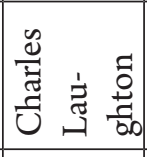 & & 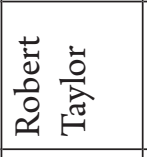 & & 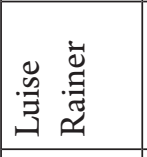 & & 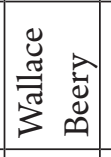 & 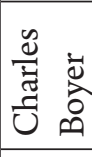 \\
\hline 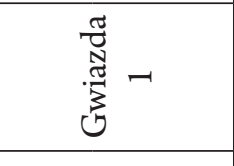 & 总 苟 & 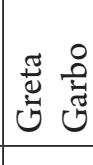 & 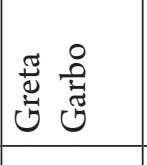 & 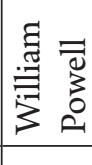 & 焉亭 & 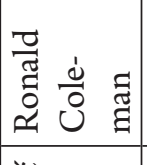 & 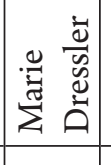 & 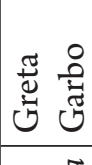 \\
\hline$\underset{E}{E}$ & 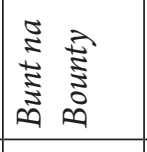 & 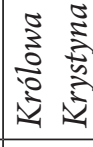 & 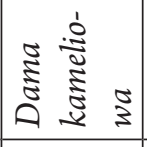 & $\begin{array}{l}3 \\
3 \\
3 \\
3 \\
3 \\
3\end{array}$ & 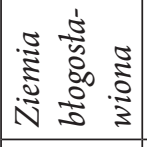 & 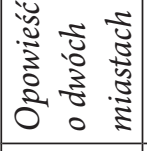 & $\mid$ & 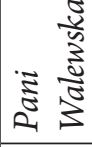 \\
\hline 合范 & - & a & $m$ & + & in & 6 & r & $\infty$ \\
\hline
\end{tabular}




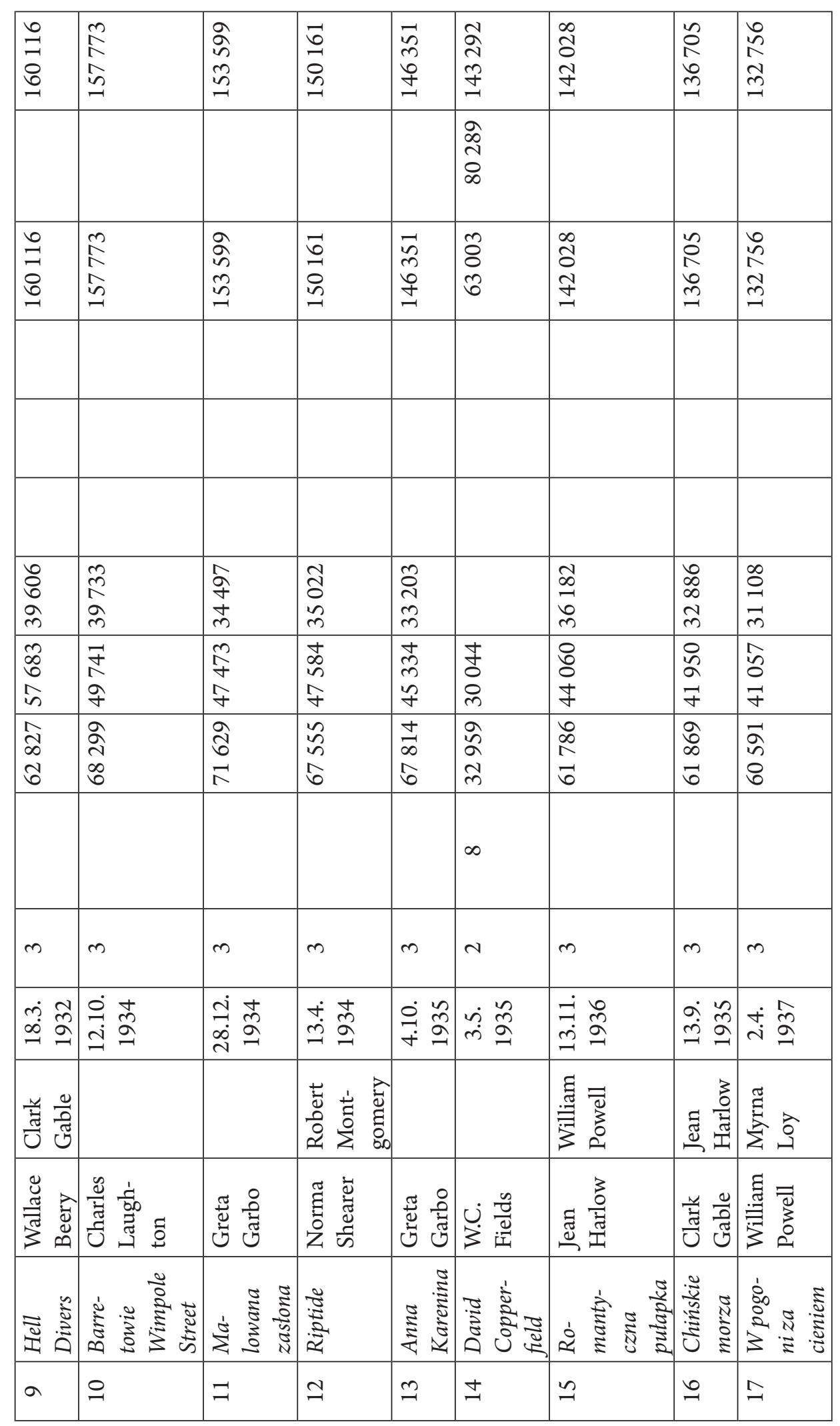




\begin{tabular}{|c|c|c|c|c|c|c|c|}
\hline 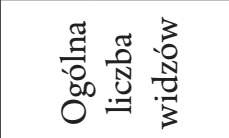 & 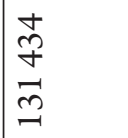 & $\begin{array}{l}\overrightarrow{0} \\
\vdots \\
0 \\
0 \\
0\end{array}$ & 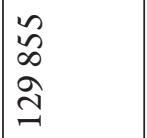 & 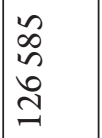 & 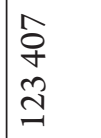 & $\begin{array}{l}1 \\
6 \\
\infty \\
\exists\end{array}$ & 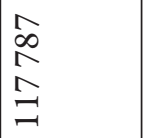 \\
\hline 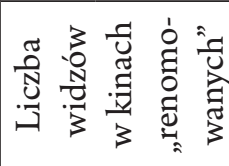 & & & & & $\begin{array}{l}m \\
\cdots \\
2 \\
2\end{array}$ & & \\
\hline 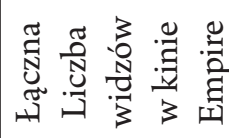 & 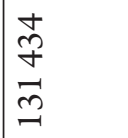 & $\begin{array}{l}\overrightarrow{5} \\
+ \\
0 \\
0 \\
\end{array}$ & 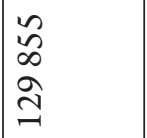 & $\begin{array}{l}2 \\
\infty \\
n \\
0 \\
0 \\
1 \\
1\end{array}$ & $\begin{array}{l}+ \\
\infty \\
\infty \\
\infty \\
D\end{array}$ & $\begin{array}{l}\hat{N} \\
\mathbf{0} \\
0 \\
\exists\end{array}$ & 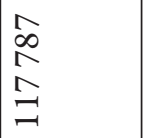 \\
\hline 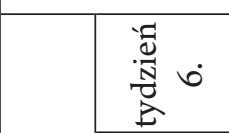 & & & & & & & \\
\hline 离 & & & & & & & \\
\hline 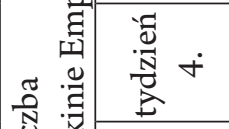 & & & & & & & \\
\hline 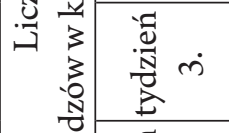 & & $\begin{array}{l}2 \\
2 \\
n \\
\end{array}$ & 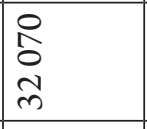 & & & & $\begin{array}{l}\text { I } \\
\text { I } \\
\text { I } \\
\end{array}$ \\
\hline $\begin{array}{ll}3 \\
\frac{\pi}{3}\end{array}$ & $\begin{array}{l}\text { 票 } \\
\text { in } \\
\text { n }\end{array}$ & $\begin{array}{l}a \\
\stackrel{a}{+} \\
\tilde{q}\end{array}$ & $\begin{array}{l}8 \\
2 \\
7 \\
7\end{array}$ & $\begin{array}{l}\infty \\
\infty \\
a \\
a \\
a\end{array}$ & & 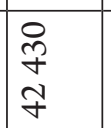 & $\begin{array}{l}0 \\
m \\
p \\
p\end{array}$ \\
\hline - & $\begin{array}{l}\text { d } \\
2 \\
n \\
2\end{array}$ & $\begin{array}{l}0 \\
2 \\
6\end{array}$ & $\begin{array}{l}n \\
\tilde{B} \\
n \\
n\end{array}$ & $\begin{array}{l}8 \\
8 \\
0 \\
0 \\
1\end{array}$ & 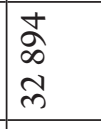 & 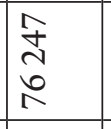 & $\begin{array}{l}2 \\
\text { in } \\
8 \\
0\end{array}$ \\
\hline 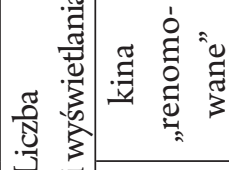 & & & & & $\infty$ & & \\
\hline 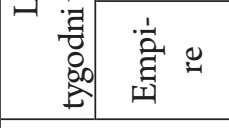 & N & $m$ & $m$ & N & -7 & N & 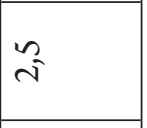 \\
\hline 㺃总总 & ஸ่ $\tilde{\Omega}$ & 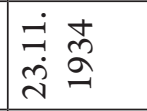 & 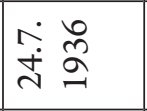 & 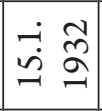 & $\begin{aligned}-\dot{a} \\
\dot{a}\end{aligned}$ & 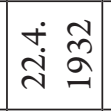 & 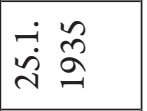 \\
\hline 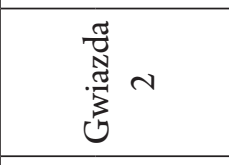 & 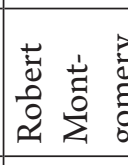 & . & 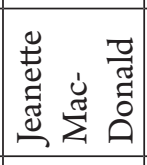 & & 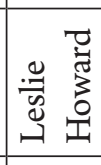 & & 总 造 \\
\hline 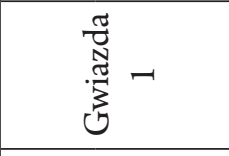 & 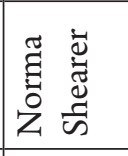 & 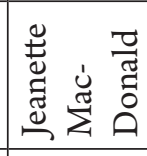 & 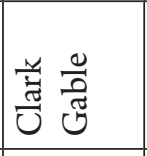 & 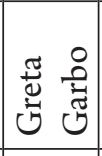 & 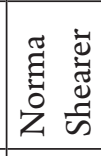 & 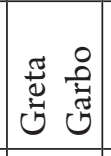 & 胥总预 \\
\hline 胥 & 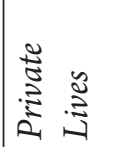 & 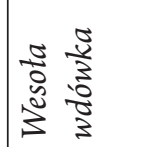 & 总 & 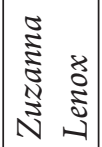 & 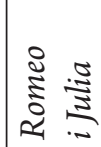 & 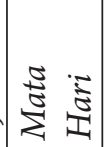 & 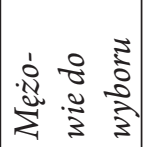 \\
\hline 商 & $\stackrel{\infty}{-}$ & 2 & i & $\overrightarrow{4}$ & A & $\approx$ & A \\
\hline
\end{tabular}




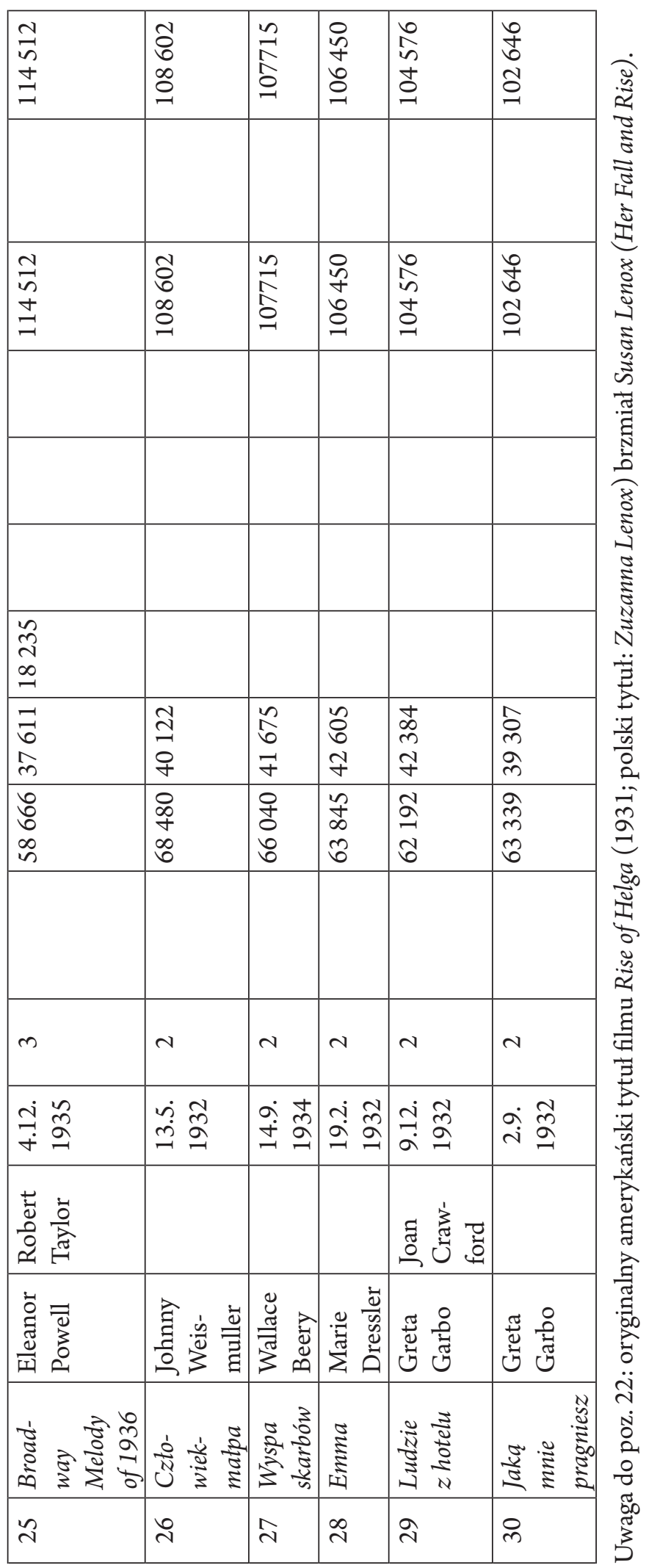




\section{Z West Endu do Bolton i Brighton}

Jak już wspomnieliśmy, widzowie Empire byli skłonni zapłacić dużo więcej niż ci spoza West Endu w zamian za przywilej obejrzenia filmów, które sami wybrali w ramach pokazów poprzedzających fazę ogólnej dystrybucji. Ta różnica cenowa $\mathrm{w}$ większym stopniu dotyczyła pięciu filmów wyświetlanymi wcześniej w kinoteatrach „o dobrej renomie”. Pokazy filmów, których listę zawiera tabela 1., odbywały się w ramach pojedynczych seansów i różniły się znacząco pod względem popularności: pierwszy film na liście zgromadził trzy razy większą publiczność niż trzydziesta pozycja w zestawieniu. Chociaż nie wiemy, kim były osoby tworzące widownię, dane te dostarczają nam podstawę do takich dociekań. $\mathrm{Na}$ przykład informacja na temat tego, jaką popularność wśród londyńskiej widowni kin zeroekranowych osiągały filmy z Gretą Garbo, jest zagadnieniem, które mogłoby okazać się interesujące dla historyków kultury czy nauk społecznych. Mogliby oni być również zaintrygowani faktem, iż zainteresowanie to wydawało się nie być tak silne wśród widowni w Bolton, gdzie Królowa Krystyna (Queen Christina, 1933) znalazła się na 20. miejscu listy filmów wyświetlanych w 1934 roku $^{19}$. Poniżej przedstawimy, jak statystyczna baza może zostać rozszerzona nawet bez faktycznych danych z zapisów kas biletowych. W oparciu o dwa opublikowane wcześniej studia przypadków dotyczących odwiedzania kin w Bolton i Brighton w latach 1934-1935 rozwinęliśmy analityczną metodę pomagającą zbadać przekazywanie filmów wyświetlanych w Empire do jednego lub większej liczby kin $\mathrm{z}$ tych dwóch angielskich miast $\mathrm{w}$ trakcie dwóch lat ${ }^{20}$. Sciślej rzecz ujmując, przyglądając się filmom wyświetlanym w trakcie tego okresu w Empire (w przypadku Davida Copperfielda również w kinoteatrze „o dobrej renomie”), możliwe okazuje się zbadanie historii ich dalszego obiegu w Bolton i Brighton. Na pierwszy rzut oka wydaje się, że widownia filmowa tej pary miast miała sposobność zobaczyć film znacznie później niż publiczność Empire. Ogólnie rzecz biorąc, Brighton wyświetlało filmy MGM w okresie od czterech do sześciu miesięcy po pokazach w londyńskim West Endzie, a jakieś dwa miesiące przed pierwszym pokazem $\mathrm{w}$ Bolton. W rezultacie $\mathrm{w}$ toku badań jesteśmy w stanie przyporządkować mniej filmów wyświetlanych w Bolton (69) w porównaniu z Brighton (85).

$\mathrm{Na}$ wykresach $3 \mathrm{a}$ i $3 \mathrm{~b}$ filmy pokazywane w Empire w ramach podwójnych seansów tworzą pionowe zbiory po prawej stronie wykresów, co oznacza, że podczas gdy różnice w łączonych pokazach w Empire były niewielkie, to gdy filmy dystrybuowane były osobno, różnice między nimi były czasem bardzo wyraźne. Na przykład, w tygodniu od 5 stycznia 1934 roku Christopher Bean (1933) wytwórni MGM oraz zrealizowany w niewielkim brytyjskim studiu The Roof (1933)

19 J. Sedgwick, Popular Filmgoing in 1930s Britain..., załącznik do rozdziału 5.

20 Ibidem, rozdziały 5 . i 6. 
Znajomość zachowań widowni na podstawie danych statystycznych... 215
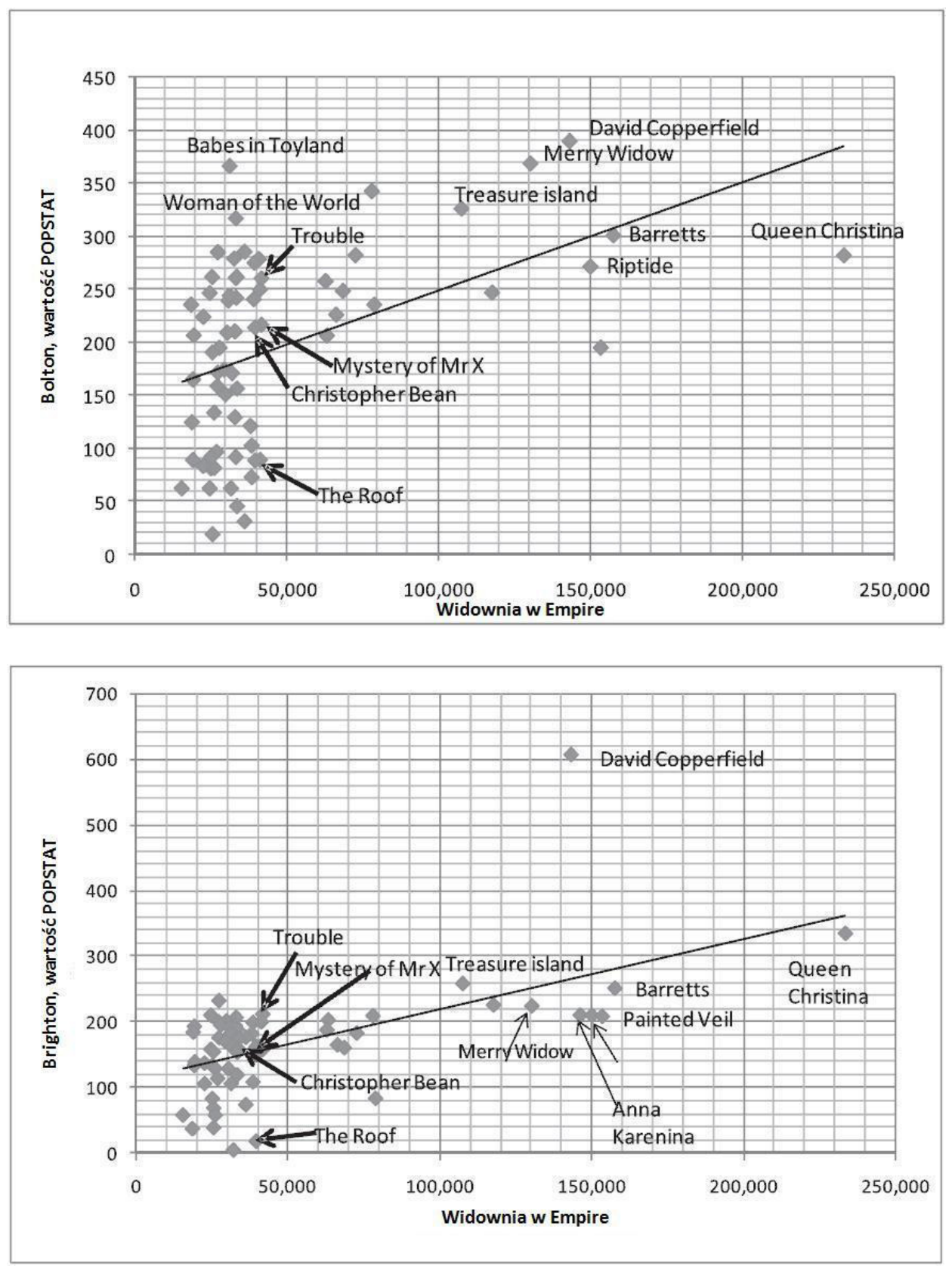

Wykres 3a, 3b. Korelacja widowni Empire z wartościami POPSTAT dla Bolton i Brighton dla filmów wyświetlanych w 1934 oraz w pierwszej połowie 1935 roku 
były wyświetlane w formie podwójnego seansu w Empire. Jednakże popularność każdego z nich mierzona odrębnie, na podstawie osobnych seansów w Bolton ( 7 w przypadku Christophera Beana oraz 3 odnośnie do The Roof) i Brighton (odpowiednio: 5 i 1), sugeruje, że w oczach widowni Empire formuła podwójnego seansu w sytuacji tego konkretnego repertuaru była zdecydowanie trafna. W innych przypadkach, takich jak łączony seans Mystery of Mr X (1934) oraz brytyjskiej komedii Trouble (1933), istniała mała różnica w popularności filmów, szacowanej tutaj na podstawie liczby przysługujących im pojedynczych seansów w Bolton (odpowiednio: 6 i 7 ) i Brighton (odpowiednio: 3 i 5).

Filmy oznaczone na wykresie po prawej stronie pionowo zorganizowanego skupiska punktów pokazywano głównie w formie pojedynczych seansów, większość z nich była wyświetlana w Empire przez dwa tygodnie lub dłużej (zob. tabela 1.). W Bolton, gdy już zostały tam przekazane, były regularnie wyświetlane pojedynczo, w posiadającym 1642 miejsca kinie Capitol. W Brighton grano je w kinie Savoy (2630 miejsc) lub Regent (2020 miejsc) i zwykle jako część seansów podwójnych - spośród 85 filmów w tej grupie tylko Królowa Krystyna i David Copperfield były wyświetlane pojedynczo.

Tabela 2. zawiera listę najważniejszych filmów wyświetlanych w tym czasie w Empire jako seanse indywidualne. Obejmuje ona ogólnokrajowe wartości POPSTAT oraz dotyczące Bolton i Brighton ${ }^{21}$. Te trzy zestawy danych zawierają odpowiednio: (1) w przypadku danych krajowych, wszystkie filmy pokazywane na przykładowej grupie 92 kin, (2) wszystkie filmy ze wszystkich kin w Bolton i Brighton. Jeśli średnia wartość POPSTAT dla każdego z tych trzech zestawów danych wynosi sto, wówczas nie jest zaskoczeniem, że filmy wymienione w tabeli 2 . wygenerowały wyniki znacząco wyższe niż średnia popularności. Warto też zauważyć, że w obu miastach filmy te były wielokrotnie wypożyczane (multiple bookings) - najwyższa wartość POPSTAT i większa liczba wyróżniających się pokazów odnotowanych przez kina w Bolton może być wytłumaczona przez praktykę pokazywania najbardziej atrakcyjnych filmów pojedynczo, bez drugiego seansu. Niemniej jednak są pewne wyraźne różnice zarówno między ogólnokrajową i lokalną recepcją filmów, jak i między tymi dwiema miejscowościami.

Na przykład wyjątkowy sukces Królowej Krystyny w Empire i w ogólnokrajowym pierwszym obiegu nie powtórzył się w żadnej z miejscowości, aczkolwiek w Brighton recepcja filmu była bardzo dobra. Podobny schemat wyłania się, choć w mniejszym stopniu, w kontekście innego filmu z Garbo znajdującego się na liście - Malowanej zastony (The Painted Veil, 1934). Z drugiej strony, $W$ pogoni za cieniem (The Thin Man, 1934) w Bolton i David Copperfield w Brighton wydawały się szczególnie atrakcyjne dla lokalnej publiczności.

${ }^{21}$ Dla szczegółowych danych krajowych zob. J. Sedgwick, Popular Filmgoing in 1930s Britain..., rozdział 4. 
Poza tymi szczegółami można powiedzieć, że filmy wyświetlane w Empire są wysoce pozytywnie skorelowane z krajową wartością POPSTAT obliczoną dla tych filmów $(\mathrm{r}=0,88)$, jak również pozytywnie skorelowane, choć w mniejszym stopniu, $\mathrm{z}$ wartością POPSTAT dla Bolton i Brighton (odpowiednio $\mathrm{r}=0,46$, i $\mathrm{r}=0,55$ ), co oznacza istnienie, wspomnianych już, różnic między miejscowościami. Są one uwydatnione na wykresie 3a, 3b, na którym linia trendu została ustalona na podstawie założenia, według którego publiczność Empire była dobrym czynnikiem prognostycznym dla widowni Bolton i Brighton (jak zmierzono POPSTAT).

Tabela 2. Filmy wyświetlane w ramach pojedynczych seansów w Empire w 1934 i 1935 roku, oraz ich dalszy obieg w Bolton i Brighton

\begin{tabular}{|l|c|c|c|c|c|c|}
\hline \multicolumn{1}{|c|}{ Tytuł filmu } & $\begin{array}{c}\text { Empire } \\
\text { frekwen- } \\
\text { cja }\end{array}$ & $\begin{array}{c}\text { Krajowa } \\
\text { wartość } \\
\text { POPSTAT }\end{array}$ & $\begin{array}{c}\text { Bolton, } \\
\text { wartość }\end{array}$ & $\begin{array}{c}\text { Bolton, } \\
\text { liczba } \\
\text { pokazów }\end{array}$ & $\begin{array}{c}\text { Brighton, } \\
\text { wartość } \\
\text { POPSTAT }\end{array}$ & $\begin{array}{c}\text { Brighton, } \\
\text { liczba } \\
\text { pokazów }\end{array}$ \\
\hline Królowa Krystyna & 233688 & 457 & 282 & 5 & 334 & 5 \\
\hline $\begin{array}{l}\text { Barretowie z Wim- } \\
\text { pole Street }\end{array}$ & 157773 & 373 & 301 & 5 & 251 & 6 \\
\hline Malowana zasłona & 153599 & 337 & 195 & 5 & 208 & 4 \\
\hline Riptide & 150161 & 350 & 271 & 5 & 209 & 4 \\
\hline Anna Karenina* & 146351 & 339 & - & - & 209 & 4 \\
\hline David Copperfield & 143292 & 491 & 390 & 6 & 606 & 6 \\
\hline Wesoła wdówka & 130401 & 413 & 368 & 7 & 224 & 5 \\
\hline Mężowie do wyboru & 117787 & 237 & 247 & 6 & 225 & 5 \\
\hline Wyspa skarbów & 107715 & 329 & 326 & 7 & 258 & 6 \\
\hline Ludzie w bieli & 78953 & 179 & 235 & 5 & 83 & 3 \\
\hline W pogoniza cieniem & 78120 & 308 & 342 & 8 & 209 & 6 \\
\hline Uwięzieni & 72825 & 224 & 282 & 6 & 182 & 3 \\
\hline Kot i skrzypce & 68645 & 239 & 248 & 6 & 160 & 4 \\
\hline Viva Villa! & 66412 & 223 & 226 & 5 & 165 & 4 \\
\hline Vagabond Lady & 63356 & 141 & 206 & 5 & 202 & 4 \\
\hline Evelyn Prentice & 62942 & 230 & 257 & 6 & 187 & 3 \\
\hline Średnia & 112378 & 302 & 278 & 5,80 & 234 & 4,53 \\
\hline
\end{tabular}

* Ponieważ Anna Karenina (1935) nie była wyświetlana w Bolton aż do początku 1936 roku, nie nie jest uwzględniona w tej części analizy, w której wyznaczono datę graniczną 31 grudnia 1935 dla badań nad kinami w Bolton i Brighton.

Uwaga: Wskaźniki są wyrażone w odniesieniu do średniej wartości POPSTAT zarówno dla zestawu danych ogólnokrajowych, jak i dla Bolton i Brighton. Każdej średniej jest dana wartość 100.

Źródło: „Bolton Evening News”, „Brighton Evening Argus”, Allen Eyles Collection, Eyles (1989), J. Sedgwick, Popular Filmgoing in 1930s Britain: A Choice of Pleasures, Exeter University Press: Exeter 2000, rozdziały 5 i 6. 


\section{Od Tuschinskiego do kin Utrechtu i Tilburga (1934-1936)}

Schemat dystrybucji filmowej w Holandii przypominał stosowany w Wielkiej Brytanii - po premierze następowało uporządkowane rozpowszechnianie filmu. W przypadku Holandii najpopularniejsze filmy miały swoją premierę mniej więcej w tym samym czasie $\mathrm{w}$ trzech dużych miastach: Amsterdamie (778 442 mieszkańców w 1934 roku), Rotterdamie (587 901) i Hadze (469 168), po której były dystrybuowane od większych do małych miast, od większych do mniejszych kin. Filmy te były wyświetlane prawie wszędzie ${ }^{22}$. Jednak, w przeciwieństwie do Wielkiej Brytanii, istnieją dowody, że niektóre produkcje z mniejszych studiów miały premiery w małych, prowincjonalnych miasteczkach ${ }^{23}$.

Tuschinski było jednym z głównych kin premierowych w Amsterdamie wyświetlających filmy z różnych wytwórni i z różnych kontekstów narodowych. Otwarte w 1921 roku, z możliwością pomieszczenia 1620 widzów, było w latach 1934-1936 największym kinem w Holandiii ${ }^{24}$. W przeciwieństwie do londyńskiego Empire, należącego do MGM, Tuschinski było własnością niezależnych biznesmenów: Hermanna Ehrlicha, Hermanna Gerschtanowitza i Abrahama Tuschinskiego, który był właścicielem dwóch innych kin w Amsterdamie, sześciu w Rotterdamie i jednego w Schiedamie ${ }^{25}$.

22 Zob. J. Sedgwick, C. Pafort-Overduin, J. Boter, Explanations for the Restrained Development of the Dutch Cinema Market in the 1930s, „Enterprise and Society” 2012, No. X, tabela 3., wykres 2.; C. Pafort-Overduin, Distribution and Exhibition in the Netherlands, 1934-1936, [w: Explorations in New Cinema History. Approaches and Case Studies, eds. R. Maltby, D. Biltereyst, P. Meers, Wiley-Blackwell, Malden: Oxford 2011; C. Pafort-Overduin, Watching Popular Films in the Netherlands 1934-1936, [w: ] Watching Films: New Perspectives on Movie-Going, Exhibition and Reception, eds. A. Moran, K. Aveyard, Intellect Books: Bristol 2012.

23 Stało się tak w przypadku niemieckiego filmu Szpiedzy z Willym Fritschem (Spione am Werk, 1933), który miał premierę 5 stycznia 1934 roku w Royal Theater w Maastricht (64 895 mieszkańców w 1934). Film ten był grany przez tydzień, po czym pojawił się ponownie miesiąc później, 2 lutego 1934 w Heerlen. Po amsterdamskiej premierze 9 lutego 1934 roku został wpisany do programu kinoteatru Alhambra na dwa tygodnie. Kolejnym przykładem jest produkcja RKO - Symphonie of Six Million (1932), który był grany przez tydzień po swojej premierze w Mabi Theater w Maastricht 5 stycznia 1934, zanim zaczął być wyświetlany w Hadze od 26 stycznia 1934.

24 Jedynie posiadający 2200 miejsc Gebouw voor kunst en Wetenschap (Building for Arts and Science) w Hadze, który od czasu do czasu wyświetlał filmy, miał więcej miejsc niż Tuschinski. Zob. www.cinemacontext.nl.

25 By uniknąć bankructwa, wszystkie te kina zostały przekazane Tubem (Tuschinski Bioscoop Exploitatie NV, Tuschinski Cinema Exploitation Inc.) w 1936, po którym to czasie trzech dyrektorów nie miało dłużej wpływu na kwestie finansowe związane z za- 
W przeciągu trzech lat (1934-1936) w kinie Tuschinski wyświetlono 111 filmów, z których dokładnie sto było premierami. Tabela 3. zawiera listę osiemnastu filmów, które przez dwa lub więcej tygodni były na afiszach ${ }^{26}$. W oparciu o historię wyświetlania wartości POPSTAT zostały odnotowane dla każdej z produkcji pokazywanej w kinie Tuschinski, ich późniejszego rozpowszechnienia wśród dużej krajowej próbki kin z dwudziestu dwóch miast i miasteczek, jak również dla wszystkich kin Tilburga i Utrechtu. (Profile zawodowe mieszkańców tych dwóch społeczności różniły się: $\mathrm{w} 1930$ roku około 45 procent siły roboczej Utrechtu było zatrudnione w sektorze usługowym, podczas gdy, dla kontrastu, 74 procent mieszkańców Tilburga pracowało w przemyśle tekstylnym) ${ }^{27}$. W badanym okresie 1934-1936 liczba kin w Utrechcie wzrosła z sześciu do siedmiu, zaś liczba miejsc z 350 (kino Olympia) do 1350 (Rembrandt). Liczba kin w Tilburgu była porównywalna z liczbą kin w Utrechcie: w 1934 roku było ich sześć, z czego jedno z nich zostało zamknięte w czerwcu 1936 roku. Jednakże liczba miejsc w tilburgskich kinach była mniejsza, od 150 do 880 . Co więcej, liczba mieszkańców przypadających na jedno miejsce była niższa - 28 w Tilburgu, 34 w Utrechcie, w 1934 roku. Dane te silnie kontrastują z liczbami z osiemnastu kin dwóch angielskich miast.

Wszystkie filmy (osiemnaście tytułów), których listę zawiera tabela 3., były również wyświetlane w Tilburgu i Utrechcie. Kolejną różnicą w schemacie dystrybucyjnym jest fakt, iż w Utrechcie połowa filmów odnotowanych w tabeli 3. była wyświetlana w kinie Rembrandt, podczas gdy w Tilburgu miały one swoje premiery w większej liczbie kin.

Tak jak w przypadku Bolton i Brighton, interesuje nas stwierdzenie, w jakim stopniu reakcje publiczności kin premierowych znajdowały swoje odzwierciedlenie $w$ innych miejscach. Przy użyciu tej samej metody kalibrowania wartości POPSTAT i analogicznie do tabeli 2., z tabeli 3. jasno wynika, że zainteresowanie ze strony publiczności kina Tuschinski dla filmów holenderskojęzycznych

rządzaniem kinami. Zob. www.cinemacontext.nl i H. van Gelder, Abraham Tuschinski, Nijgh \& Van Ditmar: Amsterdam 1996, s. 140-142.

${ }^{26}$ Jest prawdopodobne, że wartości POPSTAT przypisane filmom, które utrzymały się na ekranie kina Tuschinski przez dwa, trzy i cztery tygodnie niewystarczająco oddają stopień ich popularności. Jest to spowodowane faktem, że metodologia POPSTAT przydziela wszystkim wyświetlanym filmom, powiedzmy, jako pojedyncze seanse w danym kinie w populacji kin taką samą wartość dla każdego tygodnia wyświetlania - dlatego też w tabeli 3. wartość POPSTAT wzrasta wielokrotnie wraz z każdym tygodniem. Jak można ocenić na podstawie dochodów $\mathrm{z}$ filmów o podobnej strategii wyświetlania w Empire, procedura ta wygładza różnice we frekwencji, co stanowi jej słabość.

${ }^{27} \mathrm{H}$. Knippenberg, Twee eeuwen werk. De beroepsbevolking in kaart gebracht, [w:] Nederland in Verandering. Maatschappelijke Ontwikkelingen in Kaart Gebracht 18002000, eds. E. Beekink, O. Boonstra, T. Engelen, H. Knippenberg, Aksant: Amsterdam 2003 , s. 17, 20. 


\begin{tabular}{|c|c|c|c|c|c|c|c|c|c|c|c|c|c|c|c|c|c|}
\hline 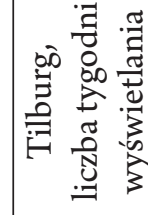 & $n$ & $\neg$ & in & 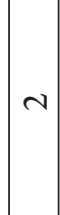 & 0 & $\sim$ & $N$ & in & -1 & $\sim B$ & $N$ & $\begin{array}{lll}0 & m\end{array}$ & $n / a$ & + & 0 & -1 & -1 \\
\hline 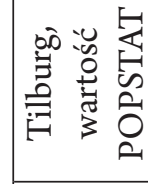 & 古 & $\approx$ & $\stackrel{\infty}{\infty}$ & î̀ & $\begin{array}{l}\infty \\
\infty \\
\infty\end{array}$ & $\overrightarrow{0}$ & $\stackrel{+}{\sim}$ & 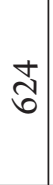 & $\begin{array}{l}n \\
n \\
n \\
n\end{array}$ & $\stackrel{2}{\beth}$ & ๑) & 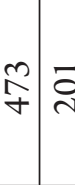 & $\begin{array}{l}5 \\
\text { s. } \\
\infty\end{array}$ & $\stackrel{ \pm}{\beth}$ & $\vec{\infty}$ & $\mid \begin{array}{l}0 \\
m \\
=\end{array}$ & $\begin{array}{l}\infty \\
\infty\end{array}$ \\
\hline 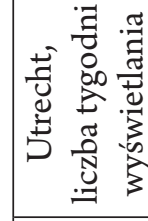 & $\exists$ & - & $m$ & $m$ & 0 & $m$ & -1 & in & -1 & $\sim 0$ & m & $m \sim$ & $v \mid N$ & $\sim$ & $m$ & -1 & - \\
\hline 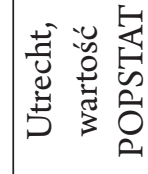 & 竎 & $\stackrel{+}{=}$ & $\stackrel{\infty}{\sim}$ & $\stackrel{n}{\Omega}$ & $\stackrel{\infty}{\sim}$ & : & 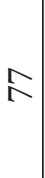 & $\Xi$ & $\hat{\Sigma}$ & $\alpha$ & 2 & 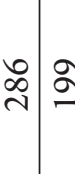 & 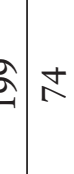 & $\stackrel{?}{ \pm}$ & $\cong$ & 岕 & 우 \\
\hline 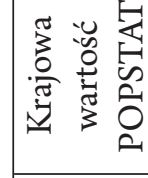 & 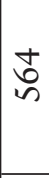 & $\underline{I}$ & $\stackrel{8}{-1}$ & $\stackrel{\infty}{\mathbb{N}}$ & 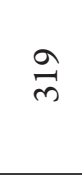 & 2 & $\hat{\sigma}$ & 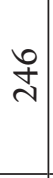 & $\begin{array}{l}0 \\
+1 \\
-1\end{array}$ & $\stackrel{\infty}{\sim}$ & $\hat{n}$ & \begin{tabular}{c|c}
$\infty$ \\
$\stackrel{1}{N}$ & $\infty$
\end{tabular} & - & 孚 & సે & $\stackrel{2}{0}$ & $\stackrel{\infty}{0}$ \\
\hline 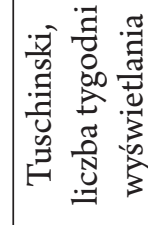 & $\theta$ & $m$ & $m$ & $m$ & $n$ & $m$ & $N$ & $\sim$ & $N$ & $\sim 0$ & $\sim A$ & $\sim \sim$ & 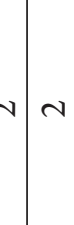 & $\sim \mid$ & $\sim$ & $N \mid$ & $v$ \\
\hline 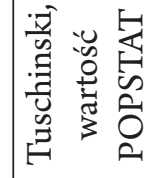 & 요 & $\stackrel{+}{\sim}$ & $\stackrel{\text { }}{\mathrm{N}}$ & $\stackrel{\circ}{\stackrel{+}{\sim}}$ & $\stackrel{\stackrel{ }{\sim}}{ }$ & 号 & $\stackrel{0}{:}$ & $\stackrel{0}{0}$ & $\begin{array}{l}8 \\
\stackrel{0}{0} \\
-1\end{array}$ & $\stackrel{0}{:}$ & $\stackrel{5}{\circ}$ & $\begin{array}{l}\circ \\
: \\
-1\end{array}$ & $\begin{array}{l}0 \\
0 \\
0\end{array}$ & $\stackrel{8}{\circ}$ & $\stackrel{8}{\circ}$ & : & $\stackrel{8}{0}$ \\
\hline 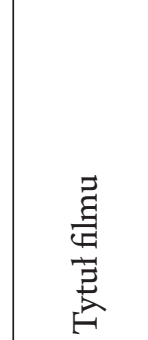 & $\frac{\stackrel{5}{5}}{\Omega}$ & 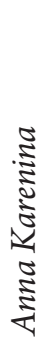 & 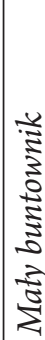 & 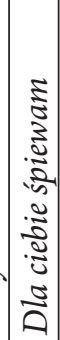 & 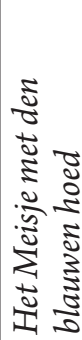 & 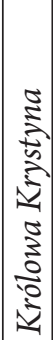 & $\begin{array}{c}5 \\
0 \\
5 \\
0 \\
0 \\
0 \\
0 \\
3 \\
0 \\
0 \\
0 \\
3 \\
3\end{array}$ & 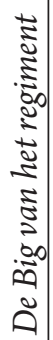 & $\begin{array}{c}: \\
\frac{3}{3} \\
\frac{2}{0} \\
0\end{array}$ & 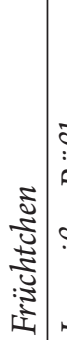 & 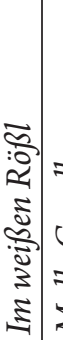 & 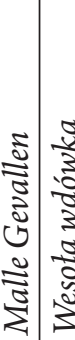 & 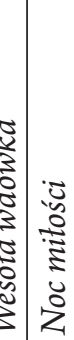 & 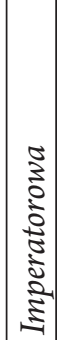 & 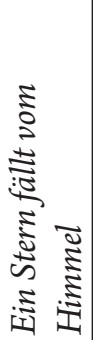 & 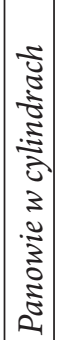 & 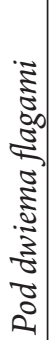 \\
\hline
\end{tabular}


powtarzało się w całym kraju (włączając Tilburg i Utrecht). Dotyczy to filmów takich, jak De Jantjes (The Sailors, 1934), Het Meisje met den blauwen hoed (The Girl with the Blue Hat, 1934), De Big van het Regiment (Baby of the Regiment, 1935) i Malle Gevallen (Silly Affairs, 1934), z których każdy miał wydłużony czas wyświetlania w tych dwóch miastach, przy czym trzy ostatnie tytuły wydają się być szczególnie popularne wśród tilburgskiej publiczności.

Dalsze badania dostarczają dodatkowych dowodów popularności holenderskojęzycznych filmów w obu miastach; siedem z dziesięciu najpopularniejszych filmów wyświetlanych w Tilburgu pochodziło od holenderskich producentów, $\mathrm{w}$ porównaniu z pięcioma $\mathrm{w}$ Utrechcie. Interesujący wydaje się również fakt, że tylko dwie premiery $\mathrm{z}$ kina Tuschinski znalazły się $\mathrm{w}$ pierwszej dziesiątce popularnych filmów w Utrechcie, podczas gdy w Tilburgu pięć znalazło się w lokalnym top dziesięć ${ }^{28}$.

\section{Dyskusja i konkluzje}

To ograniczone w swoim zakresie badanie przedstawia szczegółową analizę wydajności jednego z kin londyńskiego West Endu - należącego do MGM Empire. W kinie tym w latach 30. wyświetlano produkcje najbardziej rozrzutnej wielkiej hollywoodzkiej wytwórni, głównie premiery, aczkolwiek pięć filmów wymienionych w aneksie wyświetlono wcześniej w jednym, a w przypadku Wielkiego Ziegfelda (1936), w dwóch innych kina „o dobrej renomie”. Dane dotyczące frekwencji potwierdzają fakt, że niektóre filmy były niezwykle popularne wśród publiczności, w porównaniu ze średnią wartością frekwencji. Filmy te były fenomenami - reprezentują to, co moglibyśmy nazwać „wielkimi wydarzeniami”.

Jest prawdopodobne, że na relatywnie mniejszą skalę sytuacja taka dotyczyła kina Tuschinski w Amsterdamie. Zakres analizy jest jednak ograniczony ze względu na brak rejestrów z kas biletowych, popularność może być zatem oszacowana jedynie w przybliżeniu za pomocą metodologii POPSTAT. Sprowadza się to do przypuszczenia, że frekwencja w każdym kinie, w każdym tygodniu, była

28 W Tilburgu wszystkie one, z wyjątkiem jednego, były pokazywane w dwóch kinoteatrach należących do Hermana C. van der Waardena - Chicago Theater (700 miejsc) i w Stadsschouwburg ( 880 miejsc). Wydawałoby się, że publiczności tych dwóch kinoteatrów podobały się te same filmy, które cieszyły się sympatią publiczności kina Tuschinski. Van der Waarden wymieniał wypożyczone przez siebie filmy między swoimi dwoma kinami, planując je jako seanse wieczorne w Stadsschouwburg i popoludniowe w Chicago - jak to miało miejsce w przypadku Nocy miłości (One Night of Love, 1934). Natomiast w przypadku dwóch holenderskich filmów Het Meisje met den Blauwen Hoed i Malle Gevallen grano je w dwóch kopiach jednocześnie w obu kinach, co wskazuje, że wiązał z nimi duże nadzieje. 
identyczna, co jak wiemy z danych dotyczących Empire, nie miało miejsca. Jednakże program kina Tuschinski pokazuje, że profil „pozostałości” był podobny do tego w Empire, możemy zatem przypuszczać, że liczba sprzedanych biletów w pierwszym tygodniu była znacząco większa niż średnia, co zachęcało właścicieli kin do wydłużania okresu życia filmów na ekranie, oraz że byłoby to prawdziwe w przypadku produkcji wyświetlanych przez trzy i więcej tygodni. Ogólnie rzecz biorąc, jest prawdopodobne, że kino Tuschinski stworzyło zestaw wielkich wydarzeń - nie ma powodu przypuszczać, że profil jego dochodów różnił się od tego z Empire, co jest odnotowane na wykresie 1. i 2.

Oba kina były dobrze wyposażone, z liczną, noszącą uniformy obsługą. Były integralną częścią procesu dystrybucyjnego; wielkie produkcje filmowe były przekazywane dalej w czasie i przestrzeni - od ich wielkomiejskich premier, na przedmieścia i do prowincjonalnych miast oraz miasteczek, w ramach procesu zaprojektowanego tak, by zmaksymalizować zyski poprzez możliwie długi czas eksponowania filmu $\mathrm{w}$ bogatych kinach, zanim osiągną większość wpływów z wielokrotnego wyświetlania w mnóstwie kin prowincjonalnych. Dyspozycyjność widowni była kluczem do tej strategii: w przypadku Empire i kina Tuschinski ściągała ona widzów z szerokiego obszaru, podczas gdy na prowincji obszar ten był mniejszy, w przypadku kin dalszego obiegu ograniczony do ich najbliższej okolicy.

Analiza danych zamieszczonych w tabeli 2. i 3. oraz na wykresie 3. pozwala stwierdzić, że kasowy sukces z kina premierowego niekoniecznie powtarzał się na prowincji. By sprawdzić tę tezę, wyniki wyświetlania filmów, które miały swoje premiery w Empire w 1934 i 1935 roku, zostały prześledzone w przypadku Bolton i Brighton. Premiery z lat 1934-1936 w kinie Tuschinski skonfrontowano natomiast z projekcjami w Utrechcie i Tilburgu. Na gruncie holenderskim, filmy wyprodukowane $\mathrm{w}$ kraju okazały się niezwykle popularne $\mathrm{w}$ obu zestawach kin, podczas gdy hollywoodzkie produkcje, które utrzymywały się w kinie Tuschinski, nie zawsze były długo wyświetlane gdzie indziej, najprawdopodobniej ze względu na mniejsze zainteresowanie publiczności.

Podczas gdy Empire funkcjonowało jako kino MGM, Tuschinski korzystał z większego zakresu możliwości dystrybuowania produkcji filmowych. Stąd też w samym sercu struktury analitycznej istnieje asymetria. Niemniej jednak, jasne jest, że w kilku przypadkach, na przykład w filmach promujących Gretę Garbo, takich jak Królowa Krystyna, Malowana zastona i Anna Karenina, wyjątkowy sukces, jaki odniosły one w Empire, nie powtórzył się w Bolton (wyraźnie) czy Brighton - aczkolwiek wartość POPSTAT nadal sugeruje, że były przynajmniej dwa razy bardziej popularne od przeciętnego wyświetlanego tam filmu. David Copperfield, przyciągający widownię cztery razy większą od średniej w Empire, uzyskał wynik znacznie wyższy od linii trendu w kinach Bolton i Brighton.

Trzy filmy MGM - Anna Karenina, Królowa Krystyna i Wesota wdówka (The Merry Widow, 1934) - były wyświetlane zarówno w Empire, jak i w kinie Tuschin- 
ski w okresie, którego dotyczy ta analiza, i są odnotowane w tabelach 1., 2. i 3. Można przy tym zauważyć, że wszystkie trzy miały wydłużony czas wyświetlania w obu kinach premierowych. Jak dowiedliśmy, żaden z dwóch filmów z Garbo nie był równie popularny wśród publiczności Bolton i Brighton, niemniej jednak oba były szeroko prezentowane w lokalnych kinach różnej klasy. W Holandii, jeśli w ogóle, filmy te były mniej atrakcyjne dla lokalnej publiczności, z Anna Karenina na czele, która była wyświetlana jedynie tydzień w Utrechcie i Tilburgu.

Najbardziej zaskakujący wynik przeprowadzonej analizy dotyczy grupy filmów zaprezentowanych na wykresach $3 a$. i 3 b. Produkcje, które przyniosły średni lub mniejszy zysk kasowy w Empire, spotkały się z zupełnie innym zainteresowaniem wśród kiniarzy Bolton i Brighton, a prawdopodobnie również wśród tamtejszej publiczności. Filmy te miały swoje własne, lokalne kasowe sukcesy relatywnie do oczekiwań, jak sugeruje linia trendu, i są prawdopodobnie tak samo ważne jak wielkie wydarzenia filmowe, którymi cieszyła się publiczność kin takich jak Empire czy Tuschinski, $w$ identyfikowaniu i namyśle nad tymi wartościami, które przyciągały konkretną widownię, na konkretne filmy, w konkretnym momencie historii.

Analiza ta dostarcza statystycznej struktury do badań nad regionalną specyfiką upodobań widowni i reprezentuje kolejny rodzaj materiałów dowodowych dla filmoznawców - w oparciu o decyzje, które filmowa publiczność faktycznie podejmowała. $\mathrm{Z}$ tego punktu możliwe jest wykształcenie podejścia do wyborów filmowych w oparciu o "cechy filmu”, gdzie produkcje stanowią dowód preferencji publiczności, która poszła je obejrzeć. W ramach przykładu, we wcześniejszym studium nad popularnością filmów w Bolton, do którego odwoływano się już w tym tekście, ujawnia się fakt, że filmy z Gracie Fields były niezwykle popularne wśród tamtejszych widzów kinowych - Sing As We Go (1934) i Love, Life and Laughter (1934) uzyskały tam odpowiednio pierwsze i drugie miejsce - jak i, co jest więcej niż prawdopodobne, na całej przemysłowej północy Anglii. Jakkolwiek ten poziom popularności nie jest widoczny w londyńskim West Endzie, gdzie na przykład Sing As We Go, mający premierę w kinie Plaza, wyświetlany był w ramach pojedynczych seansów przez dwa tygodnie. W kinach Brighton i Portsmouth film ten był odpowiednio 15. i 65. w rankingu. Fields wciela się w tym musicalu w rolę, która znalazła silny oddźwięk wśród lokalnej publiczności: pracownicy fabryki z północy, która zostaje zwolniona i wyrusza do nadmorskiego kurortu Blackpool, gdzie staje się bohaterką wielu komicznych przygód. Niezwykła popularność, jaką film cieszył się w Bolton, jest podobna do sukcesu, który odnosily holenderskojęzyczne filmy wśród holenderskiej publiczności wszędzie w Holandii. Stąd elementem, który wydaje się być ceniony przez publiczność, jest identyfikacja z tematem filmu, a dowód empiryczny może zapewnić prosta metoda ilościowa, nawet jeśli jedynym dostępnym źródłem danych jest tylko repertuar kina. 